\title{
BARK ANATOMY OF LATE PERMIAN GLOSSOPTERID TREES FROM ANTARCTICA
}

\author{
Anne-Laure Decombeix ${ }^{1, *}$, Edith L. Taylor ${ }^{2}$, and Thomas N. Taylor $\dagger^{2}$ \\ ${ }^{1}$ CNRS and Université Montpellier 2, UMR AMAP, Montpellier 34000, France \\ ${ }^{2}$ Department of Ecology and Evolutionary Biology, and Natural History Museum and \\ Biodiversity Institute, University of Kansas, Lawrence, KS 66045-7600, U.S.A. \\ *Corresponding author; e-mail: anne-laure.decombeix@cirad.fr
}

\begin{abstract}
The Glossopteridales are an extinct group of seed plants that dominated Gondwanan floras during the Permian. Their remains are found across a wide range of habitats and paleolatitudes, and it is particularly interesting to understand the anatomical characteristics that might have enabled such an extensive distribution. Here, we document for the first time the bark anatomy of high-latitude glossopteridalean trees using peels and thin sections made from a Late Permian trunk from Skaar Ridge, Antarctica. The bark is $3 \mathrm{~cm}$ thick. The secondary phloem is composed of sieve cells, axial and ray parenchyma, and fibers arranged in discontinuous unicellular tangential layers. The outer bark is a rhytidome, with numerous alternating layers of periderm and non-conducting secondary phloem showing some proliferation of the axial parenchyma. Successive periderms mostly run parallel to the cambium, with some longitudinal undulation and rare connections between two periderms. A similar anatomy was observed in bark fragments found isolated in the matrix or closely associated with large glossopterid stems or roots. The anatomy of the Skaar Ridge specimens shows that Antarctic Glossopteridales had a relatively thick, probably stringy bark. The retention of a significant amount of insulating dead bark tissue on the trunk likely provided protection of the cambium, conducting secondary phloem, and potential latent buds against biotic and abiotic environmental hazards (fire, frost, scalding, insects, etc.) and may have contributed to the extensive paleolatitudinal distribution of the Glossopteridales during the Permian.
\end{abstract}

Keywords: Paleobotany, Paleozoic, high latitude, Glossopteridales, secondary xylem, secondary phloem, rhytidome.

\section{INTRODUCTION}

The Glossopteridales are a group of seed plants of Permian and possibly Triassic age (Taylor et al. 2009 and references therein). Their distinctive leaves (Glossopteris), roots (Vertebraria), and reproductive structures have been reported from all parts of Gondwana, i.e., the southern continents of today. The importance of the group is threefold. First, from an historical perspective, the distribution of Glossopteris leaves across Africa, Australia, Antarctica, India, and South America provided significant support in 
the early $X^{\text {th }}$ century to the continental drift theory (Wegener 1915) and the reconstruction of the supercontinent Gondwana. From an evolutionary perspective, the reticulate leaves of the glossopterids have sometimes been compared to those of the dicotyledons and their complex reproductive structures to the angiosperm carpel, (e.g., Plumstead 1956; Stebbins 1974; Retallack \& Dilcher 1981; Taylor \& Taylor 1992). Finally, from a paleoecological perspective, the glossopterids appear as a major component of Permian ecosystems in Gondwana. Their abundant remains document an extensive paleolatitudinal distribution, from temperate to periglacial climatic zones (McLoughlin 2011 and references therein). In addition, the Glossopteridales are found in various depositional environments, from peatlands to well-drained environments, lakes, and even uplands (e.g., Cúneo et al. 1993). This distribution is particularly interesting in that it provides an example of a woody Paleozoic taxon adapted to a very large range of environmental conditions. In particular, the Glossopteridales rapidly colonized the high latitudes of Gondwana as the ice sheets retreated during the end-Permian (Isbell \& Cúneo 1996). While today the tree line is at $64-72^{\circ} \mathrm{N}$, the greenhouse climate of the end-Permian allowed glossopteridalean trees to form forests at latitudes above $75^{\circ} \mathrm{S}$, and probably up to $85^{\circ} \mathrm{S}$ (Grunow 1999; Scotese 2002). There, they grew under a more extreme light regime than any extant tree, with 4-5 months of perpetual light in summer and darkness in winter.

Anatomically preserved fossils of Glossopteridales from such high paleolatitudes offer us unique insights into the biology of these plants (Pigg \& Nishida 2006; Slater et al. 2015). In the last decade, well-preserved specimens from Antarctica have in this way provided details on tree growth and productivity in warm polar forests (Taylor \& Ryberg 2007; Miller et al.2016), on the anatomy and development of the unusual Vertebraria root system (Decombeix et al. 2009), on the ability of the glossopterids to produce epicormic shoots that could regenerate their crown (Decombeix et al.2010a), and on the co-occurrence of deciduous and evergreen species (Gulbranson et al.2014). In addition, information on glossopterid interactions with arthropods (Slater et al. 2012) and fungi (Harper et al. 2013) gradually allows us to understand the Permian high-latitude forests as complex ecosystems.

In this paper we focus on an important aspect of glossopterid vegetative anatomy that has not been studied in detail: their bark. While this tissue is rarely preserved in the fossil record, it can provide significant taxonomic and physiological information. Among its many roles, the bark of seed plants contains the secondary phloem, which redistributes photosynthates, hormones, and other essential components through the plant. The dead tissues of the outer bark protect the functioning part of the secondary phloem and the vascular cambium against biotic and abiotic hazards. A small amount of preserved secondary phloem was reported in the stem Glossopteris skaarensis (Pigg \& Taylor 1993) and in Vertebraria roots from Skaar Ridge (Decombeix et al. 2009). However, in both cases only a few layers of the tissue were present and the composition and organization of the tissue were unclear. Here, we describe well-preserved bark associated with glossopterid remains occurring in Late Permian silicified peat from the Central Transantarctic Mountains. This new information is placed in the context of bark evolution in seed plants and of the biology of high-latitude Glossopteridales. 


\section{MATERIAL AND METHODS}

\section{Geographical and geological settings}

The specimens described in this paper occur in silicified peat blocks from the Skaar Ridge locality, Beardmore Glacier region, Central Transantarctic Mountains, Antarctica (Fig. 1A; 84 49919.10 S, 163 20928.00 E; elevation: 2,289 m). These peat blocks occur within the Buckley Formation of the Beacon Supergroup. A Late Permian age has been assigned to the Buckley Formation based on palynomorphs and associated floras (Farabee et al. 1991). The reconstructed position of the locality for the Late Permian is well within the southern polar circle (Fig. 1B) and it corresponds to some of the highest paleolatitudes at which the Glossopteridales were growing.
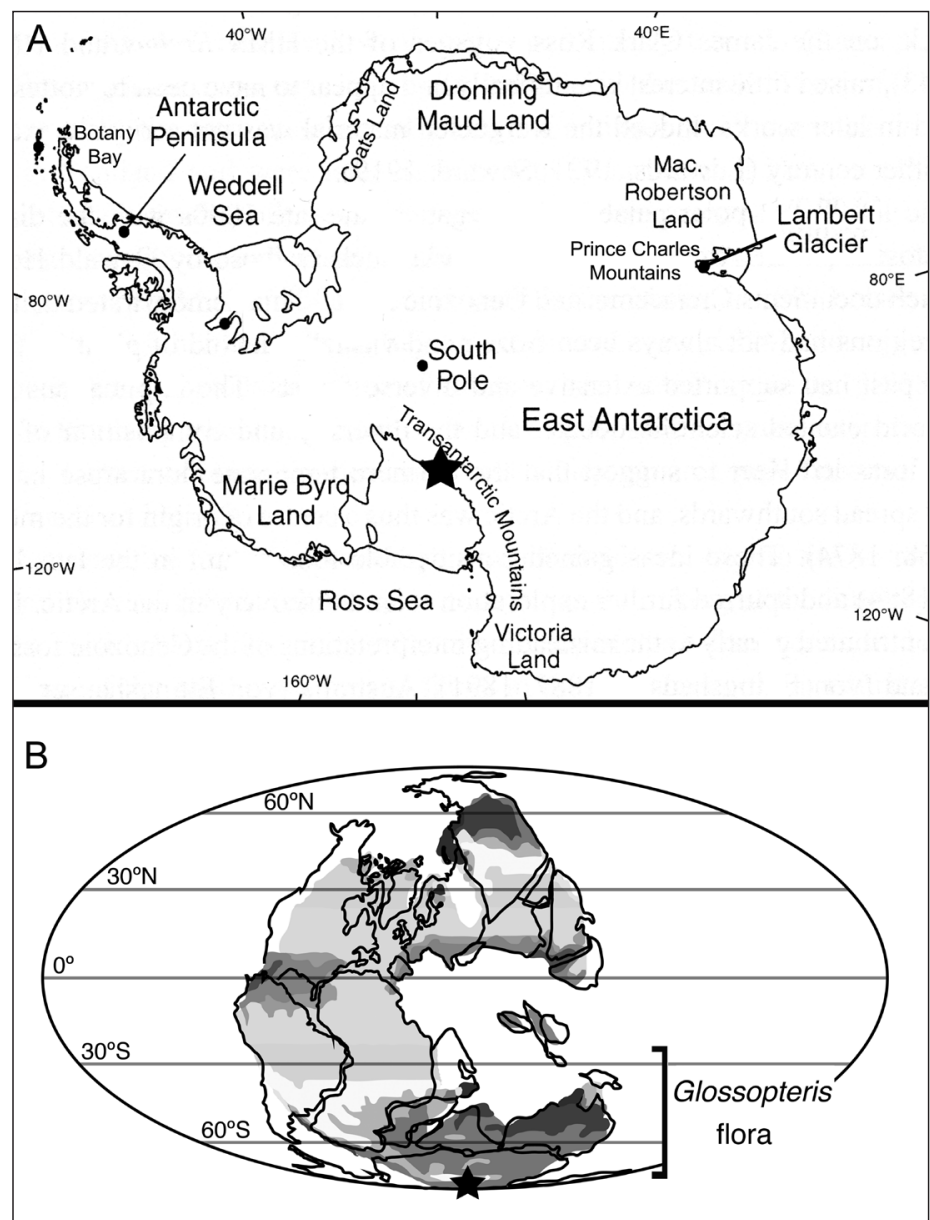

Figure 1. Position of the locality today and during the Late Permian. - A: Map of Antarctica, the star indicates the position of Skaar Ridge. Modified from Cantrill \& Poole (2013). - B: Latest Permian paleogeographic reconstruction showing climatic zones, latitude of the occurrence of Glossopteridales, and the position of the locality at that time: star, modified from Gulbranson et al. (2014). 


\section{Assignment of the specimens to the glossopterids}

Fragments of gymnosperm bark are moderately common within peat blocks from Skaar Ridge, and all the observed specimens show the same anatomy. The Skaar Ridge flora, like nearby compression floras (Cúneo et al. 1993), is largely dominated by unquestionable remains of the glossopterids such as Glossopteris leaves, Vertebraria roots, and reproductive structures (Taylor \& Taylor 1990). However, other gymnosperm taxa also may have been present. There are, for example, rare occurrences in the peat of gymnosperm roots with a non-Vertebraria anatomy (Decombeix et al. 2009). In addition, different morphogenera of stems have been reported from the Permian of Antarctica (e.g., Maheshwari 1972; Decombeix et al.2012) and it is unknown whether all belonged to the glossopterids. To take into account this uncertainty, we looked for bark that would be more closely associated with glossopteridalean remains. The key specimen presented in this paper corresponds to a trunk with the Australoxylon-type of wood typically found in glossopterid stems and roots (e.g. see illustrations and discussions in Mussa 1978; Prasad \& Chandra 1978; Neish et al. 1993; Weaver et al. 1997; Bamford 1999; Decombeix et al. 2009, 2010). A sector of the trunk has 2.5 to $3 \mathrm{~cm}$ of bark still attached. The cambial zone is partly preserved, providing unequivocal evidence that similar bark fragments found around large woody stems and roots or fragmented in the matrix do indeed belong to the glossopterids. The following description is based on this single specimen as it is the best preserved, but observation of additional material shows a similar anatomy. This includes isolated bark fragments from the silicified peat, another, less-well preserved trunk with attached bark (specimen \#16,494), and a large Vertebraria root with a thick layer of bark tissue on its periphery (specimen \#13,686).

\section{Preparation of the specimens}

The silicified peat blocks containing the bark remains were etched for 3-4 min in $49 \%$ hydrofluoric acid and serial cellulose acetate peels were made using the standard technique (Galtier \& Phillips 1999). Selected peels were mounted in Eukitt (O. Kindler, Freiburg) on microscope slides for observation. Because of unequal preservation in the bark, thin sections (Hass \& Rowe 1999) in the transverse and longitudinal planes were also prepared in order to obtain thicker sections with a better preservation of the most fragile cell walls. Observations and photography were conducted using Sony XCDU100CR digital cameras attached respectively to an Olympus SZX12 stereomicroscope and to an Olympus BX51 compound microscope. Images were captured using Archimed software (Microvision Instruments, Evry, France) and plates were composed with Adobe Photoshop CS5 version 12.0 (Adobe Systems, San José, California, USA). Transformations made in Photoshop include cropping, rotation, and adjustment of brightness and contrast for the whole image. Average measurements are given for $n=30$. The trunk, peels, and slides are deposited in the Paleobotanical Collections, Natural History Museum and Biodiversity Institute, University of Kansas (KUPB), under the specimen accession number 15,508 and slide accession numbers 30,267-30,274; 30,$273 ; 30,277$, and 29,976-29,978. Additional specimens prepared for this study are deposited under the specimen accession numbers 13,686 and 16,494 and slide accession number 30,275 . 


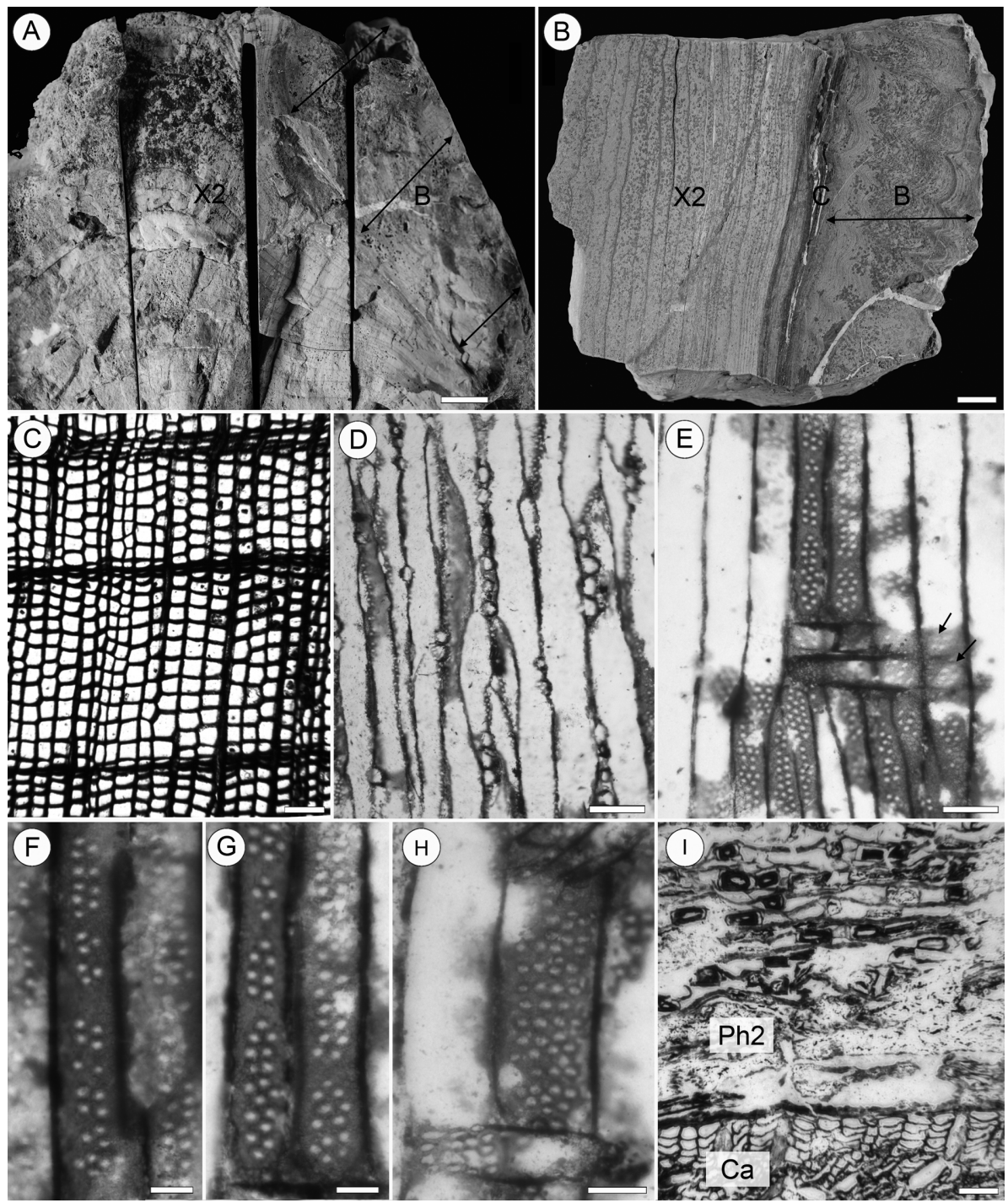

Figure 2. General aspect, wood and cambial anatomy. - A: General aspect of specimen \#15,508 viewed in transverse section and showing a portion of bark (B, double-headed arrows) still attached to the secondary xylem (X2). - B: General aspect of the specimen in longitudinal section showing the wood (X2), cambial region (C), and bark (B) with an undulated outline.C: Transverse section of secondary xylem with three growth-ring boundaries. Slide 30,270 (15508-Cside $3 \beta)$. - D: Low and uniseriate secondary xylem rays in tangential section. Slide $30,272(15508-\mathrm{D} 3 \alpha)$. - E: Radial section of secondary xylem with mixed radial pitting and crossfield pitting (arrow). Slide 30,267 (15508-Btop 1 $\alpha$ ). - F: Detail of tracheid pitting. Slide 30,267 (15508-Btop $1 \alpha$ ). - G: Detail of tracheid pitting. Slide 30,267 (15508-Btop 1 $\alpha$ ). - H: Detail of tracheid. Slide 30,272 (15508-D3 $\alpha$ ). - I: Cambial zone (Ca) and innermost secondary phloem $(\mathrm{Ph} 2)$ in transverse section. Slide 30,269 (15508-Cside 1). - Scale bars of A, B $=10 \mu \mathrm{m}$, of $\mathrm{F}, \mathrm{G}, \mathrm{H}=25 \mu \mathrm{m}$, of $\mathrm{D}, \mathrm{E}, \mathrm{I}=50 \mu \mathrm{m}$, of $\mathrm{C}=100 \mu \mathrm{m}$. 


\section{Nomenclature}

The term bark is used here as defined by Esau (1965, p. 272) to include all the tissues located outside the vascular cambium, i.e., secondary phloem, primary phloem (if still present), primary cortex (if still present), and periderm. "Inner bark" is used to designate the tissues located between the cambium and the innermost periderm and "outer bark" to designate all tissues located beyond that innermost periderm.

\section{RESULTS}

The amount of preserved secondary xylem is a little more than $7 \mathrm{~cm}$ in width (Fig. 2A, B). The central portion of the trunk is not present and, based on the slight curvature of the growth ring boundaries, the complete trunk was considerably larger. The secondary xylem is typically of the Australoxylon type (Marguerier 1973): distinct growth rings (Fig. 2C), square to rectangular tracheids in transverse section, low and uniseriate rays (Fig. 2D), small and crowded cross-field pits, and three types of radial pitting on the tracheid walls (araucarioid, abietinean, and conspicuous arrangements in groups of 2-5 pits) (Fig. 2E-H). The attached bark can be up to $3 \mathrm{~cm}$ thick (Fig. 2A, B). The inner bark consists of secondary phloem with discontinuous layers of fibers that are one cell thick radially. The outer bark is of the rhytidome type, with alternating layers of periderm and non-conducting secondary phloem (Fig. 3A). Numerous successive periderms are preserved in the trunk. In transverse section, they mostly run parallel to the cambium and rarely curve inwards and connect to the previous periderm layer (Fig. 3A). In longitudinal section, the periderms also remain mostly parallel to one another but have a slightly undulated outline (Fig. 2B, 3B).

The cambial zone is poorly preserved (Fig. 2I, 3C). The inner bark is approximately $400 \mu \mathrm{m}$ thick and composed of secondary phloem containing sieve cells, axial and ray parenchyma, and fibers (Fig. 3A-E). Poor preservation makes it difficult to delimit the boundary of the conducting part of this tissue. Like the secondary xylem rays, the phloem rays are uniseriate and a few cells high (Fig. 3G). Phloem ray cells are 20-23 $\mu \mathrm{m}$ high and 13-16 $\mu \mathrm{m}$ wide in tangential section and are procumbent in radial section. In transverse section, the fibers have a rectangular shape, with a tangential diameter of 21-51 $\mu \mathrm{m}$ (average $37 \mu \mathrm{m}$ ) and a radial diameter of 11-29 $\mu \mathrm{m}$ (average $21 \mu \mathrm{m}$ ); their wall thickness is $3-18 \mu \mathrm{m}$ and the lumen is oval to slit-like. Fibers are moderately abundant and they tend to form discontinuous layers that are only one cell thick in radial direction. (Fig. 3D, E, I). In some well-preserved areas, fibers have been observed very close to the cambium (Fig. 3C) and it is hypothesized that they were part of the conducting phloem and not the result of a later thickening of thin-walled cells.

Axial parenchyma cells are isodiametric and range from 14-55 $\mu \mathrm{m}$ in diameter (Fig. 3D-H). It must be noted that the axial parenchyma is badly preserved in the innermost part of the secondary phloem (Fig. 3C) and that measurements were taken beyond the first periderm, when these cells might have already increased in diameter. Indeed, between the successive periderms, the non-conducting secondary phloem shows a proliferation of the axial parenchyma that tends to disorganize the layers of fibers. In addition, most parenchyma cells in the non-conducting secondary phloem show some degree of wall disintegration which gives the tissue a slightly spongy aspect (e.g. Fig. 3I). 


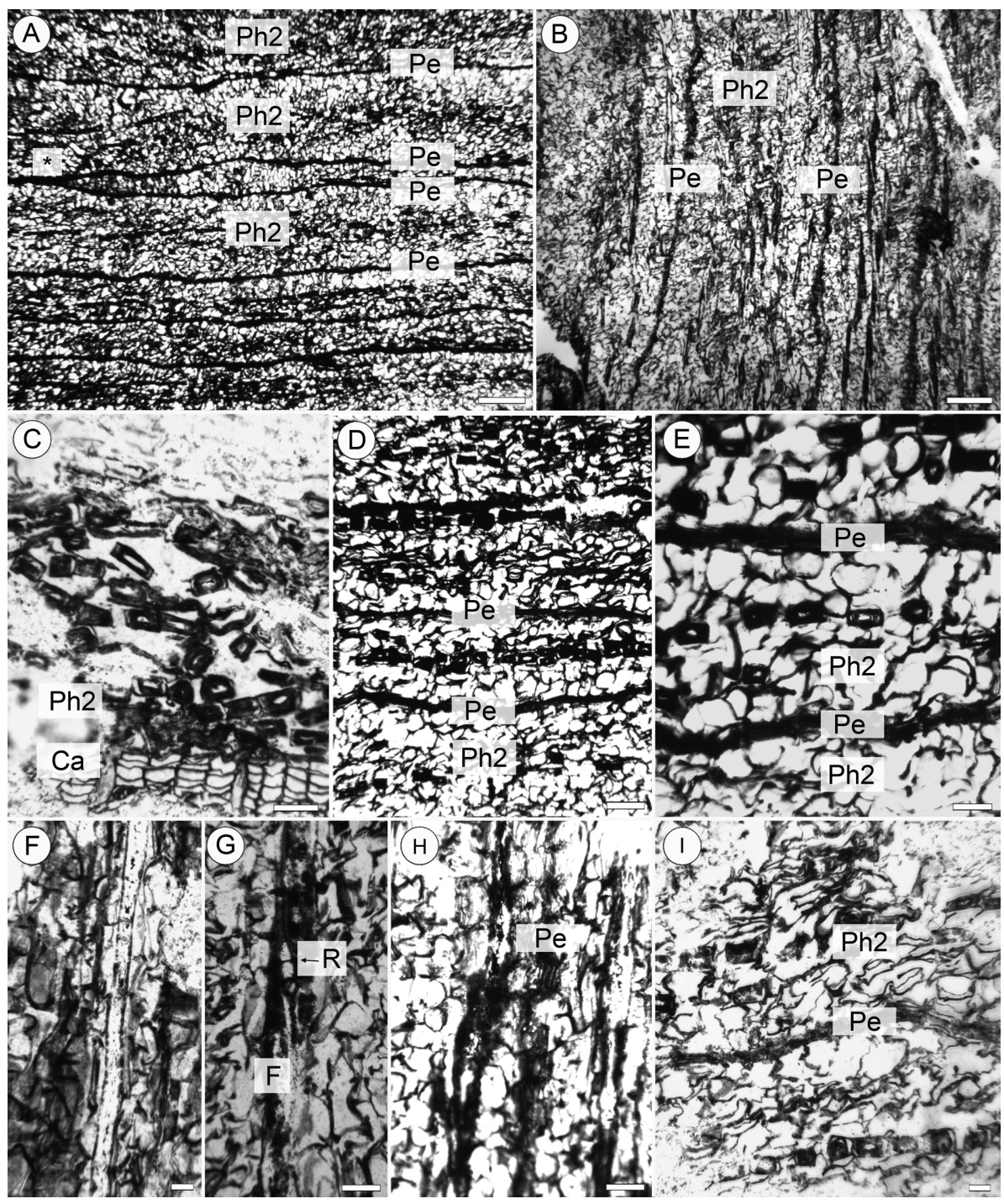

Figure 3. Bark anatomy. The cambium is located towards the bottom on all transverse sections and on the left on all longitudinal sections. - A: General view of the bark in transverse section showing the layers of secondary phloem $(\mathrm{Ph} 2)$ and several successive periderms $(\mathrm{Pe})$. The asterisk (left) indicates a connection between two layers of periderm. Slide 30,269 (15508-Cside 1). - B: General view of the bark in longitudinal section showing the layers of secondary phloem $(\mathrm{Ph} 2)$ and several successive periderms (Pe). Slide 30,273 (15508-D3ß). - C: Transverse section of cambial zone $(\mathrm{Ca})$ and innermost secondary phloem $(\mathrm{Ph} 2)$ with only fibers preserved. Slide 30,269 (15508-Cside 1). - D: Transverse section of the bark beyond the first layer of periderm showing successive layers of periderm $(\mathrm{Pe})$ and non-conducting secondary phloem with fibers $(\mathrm{Ph} 2)$. Slide 30,269 (15508-Cside 1). - E: Detail of the same region in D showing two successive layers of periderm $(\mathrm{Pe})$ and the secondary phloem $(\mathrm{Ph} 2)$. Note the expanded outline of the axial 
While this might be an artifact of preservation, it has been observed in all studied bark fragments from Skaar Ridge and the occurrence of such a spongy bark is well-documented in some extant trees such as Eucalyptus (Chattaway 1953). Poor preservation of the inner bark prevented us from observing in detail the characteristics and distribution of sieve cells but their presence is indicated by the occurrence of elongated thin-walled cells in the inner layers of the rhytidome (Fig. 3F).

The successive periderms are located $0.2 \mathrm{~mm}$ to $1.5 \mathrm{~mm}$ apart (commonly around $500-700 \mu \mathrm{m}$ in the inner part). The outer periderms are more spaced than the inner ones, likely due to the proliferation of the secondary phloem parenchyma. Periderm layers are 25-35 $\mu \mathrm{m}$ thick in transverse section (Fig. 3I). Each one is marked by 3-5 cells that are extremely flattened in the radial plane and have dark, slightly thickened walls (Figs. 3H, I). The successive periderms mostly run parallel to the cambium. They very rarely curve inwards and connect to the previous periderm layer in transverse section (Fig. 3A).

\section{DISCUSSION}

\section{Evolutionary context}

In plants with a bifacial vascular cambium (lignophytes, Kenrick \& Crane 1997), the bark tends to separate from the wood cylinder at the level of the cambium. As a result, fossil lignophyte axes are often found in a decorticated state and the number of taxa to which we can compare the bark anatomy of the glossopterid trunk from Skaar Ridge is limited.

The secondary phloem anatomy seen in the glossopteridalean trunk from Antarctica, with axial parenchyma, sieve cells, and discontinuous layers of fibers is an organization first documented in the Late Devonian progymnosperm (Archaeopteris/Callixylon, Decombeix \& Meyer-Berthaud 2013) and still present in some extant gymnosperms, for example in the Cupressaceae (e.g., Den Outer 1967). Better-preserved specimens are needed, however, to analyze this tissue in more detail, especially regarding the characters of the sieve cells.

Among fossil lignophytes for which axes with the bark still attached have been found and studied, few show a rhytidome type of outer bark. However, there is good evidence that the formation of a rhytidome existed relatively early in seed plant evolution. The oldest examples are found in arborescent seed plants of Early Carboniferous age. A first type is found in a Tournaisian tree from Australia, characterized by a

parenchyma cells in the phloem. Slide 30,269 (15508- Cside 1). - F: Longitudinal section of the secondary phloem in the outer bark. Slide 30,273 (15508-D3ß). - G: Longitudinal section of the secondary phloem in the outer bark showing expanded axial parenchyma cells, a small uniseriate ray in tangential view $(\mathrm{R})$ and part of a fiber $(\mathrm{F})$. Slide 30,273 (15508-D3 $\beta)$. - H. Longitudinal section in the outer bark showing the radially flattened, thicker-walled cells of a periderm layer. Slide 30,273 (15508-D3 $\beta$ ). - I. Transverse section in the outermost part of the bark showing the secondary phloem with expanded and degraded axial parenchyma cells and some fibers, as well as a layer of periderm $(\mathrm{Pe})$ with radially flattened dark cells. Slide 30,271 (15508-Cside 2). Scale bars of $A, B=250 \mu \mathrm{m}$, of $\mathrm{D}, \mathrm{I}=100 \mu \mathrm{m}$, of C, E, G, H = 50 $\mu \mathrm{m}$, of F $=30 \mu \mathrm{m}$. 
$1.5 \mathrm{~cm}$ thick bark (Decombeix 2013). The secondary phloem contains conspicuous bands of fibers that are several cells in radial thickness. At least four sequent periderms were observed within this fossil trunk. They are not parallel to one another and tend to connect often, which suggests that this bark was shed as small scales. In Stanwoodia kirktonensis from the Viséan of Scotland, the periderm also forms relatively small scales (Galtier \& Scott 1991). A major difference is that the phloem fibers do not form thick tangential layers but are isolated or in discontinuous, one-cell thick layers. A rhytidome outer bark was also reported in other Early Carboniferous arborescent seed plants of Viséan-Serpukhovian age, including Eristophyton beinertianum (Scott 1902), Eristophyton fasciculare (Galtier et al. 1993), and Endoxylon zonatum (Scott 1924). Among Late Carboniferous plants, the only detailed report of a rhytidome bark is in the Cordaitales. Taylor (1988) described layers of periderm in Cordaixylon that are curved and overlapping, which also suggests the formation of scales. Degani-Schmidt and Guerra-Sommer (2016) recently reported well-preserved secondary phloem attached to Agathoxylon charcolified wood from the Permian of Brazil. The affinities of the specimens are thought to be either with the Glossopteridales or the Cordaitales. The secondary phloem is composed of sieve cells in tangential layers alternating with mixed rows of fibers and axial parenchyma; the outer organisation of the bark is unknown (Degani-Schmidt \& Guerra-Sommer 2016).

The Mesozoic fossil record contains a few examples of well-preserved rhytidomes in conifers. This includes 1) Araucarioxylon arizonicum from the Triassic of the USA that is characterized by curving lenses of sequent periderms (Ash \& Savidge 2004), 2) Telemachus /Notophytum krauselii from the Triassic of Antarctica, which has several successive concentric layers of periderm (Meyer-Berthaud \& Taylor 1991; Bomfleur et al. 2013), and 3) Taxodioxylon gypsaceum from the Cretaceous of Canada (Ramanujam \& Stewart 1969). Apart from conifers, Artabe et al. (1999) reported a rhytidome in the corystosperm Rhexoxylon brunoi from the Triassic of Argentina but did not illustrate anatomical details. The existence of a rhytidome in the Antarctic corystosperm Kykloxylon fremouwensis was hypothesized by Decombeix et al. (2010b) but currently remains equivocal. The relatively small number of reports on rhytidome type bark in the fossil record is probably due to the fact that although this type of bark is often preserved, it is found detached from the parent plant and affinities are uncertain. In the case of the glossopterids, isolated fragments of bark have been reported previously at localities such as Skaar Ridge or in the Prince Charles Mountains (Slater et al. 2015) but this is the first time that anatomy has been studied from bark still attached to a stem.

\section{Outside aspect of the bark in the Antarctic glossopterid tree}

The well-preserved bark remains reported in this study allow us to have a better idea of the external features of the bark of the Skaar Ridge glossopterid trees. A first set of information is provided by the shape of the sequent periderms. Their undulated aspect in longitudinal section suggests the presence of shallow (c. $5 \mathrm{~mm}$ ) horizontal furrows. In extant trees such horizontal furrows can be found all over the trunk (e.g. Leucadendron argenteum, Proteaceae) or they can be limited to a portion of the trunk, 
usually in the oldest parts. Fragments of bark found isolated in the peat do not always show this longitudinal undulation so the second option is much more likely. The regular concentric organization of the periderms in transverse section suggests that the oldest bark did not form longitudinal furrows. Finally, the infrequent connection between two successive periderms rules out that the bark detached as small scales.

A second indication on the external aspect of the bark is provided by the anatomy of the non-conducting phloem trapped between the layers of periderm: relatively loose and with small tangential layers of fibers. Extant trees in which non-conducting phloem fibers are arranged in thin layers tend to have a stringy bark, versus a rough bark that results when fibers are organized in thick multicellular layers or blocks (Roth 1981). Good examples of extant species that have a bark anatomy comparable to our Permian specimen are Libocedrus bidwillii (Chan 1985) and Fitzroya cupressoides (De Magistris \& Castro 2001) in the Cupressaceae. Similarities include 1) a secondary phloem with layers of fibers that are only one cell thick and often discontinuous, 2) proliferation of the axial parenchyma in the non-conducting phloem, 3) numerous thin periderms that are only a few cells in thickness, 4) dead periderms and phloem retained as successive sheets on the trunk and forming a rhytidome several centimeters in thickness (Chan 1985; De Magistris \& Castro 2001). Fitzroya cupressoides typically has a stringy bark with a fibrous aspect that can be 3-9 cm in thickness (De Magistris \& Castro 2001). Libocedrus bidwillii has a $5-10 \mathrm{~cm}$ thick bark that is exfoliated as thin fibrous strips. We hypothesize that the trunk from Skaar Ridge had a comparable external aspect. It must, however, be noted that young axes or more distal parts of the trunk might have had a smoother bark, as such a variation is often seen in extant trees (e.g., Roth 1981).

While secondary phloem anatomy is relatively consistent within a plant genus, the anatomy and thickness of the rhytidome can be highly variable, as exemplified in Quercus (Graça \& Pereira 2004; Sen et al. 2011; Quilhó et al. 2013) or Eucalyptus (Chattaway 1953). It is thus impossible at this stage to know whether all species of glossopterids had similar bark or if there were differences in anatomy and/or thickness between taxa, habitats, or paleolatitudes. Further finds of well-preserved glossopterid bark from other localities will hopefully answer this question.

\section{Ecological implications}

The occurrence of a rhytidome that is several centimeters in thickness provides important information in understanding the biology of glossopterid trees. This relatively thick and insulating bark would offer good protection of the vascular cambium from biotic and abiotic hazards.

The glossopterids from Skaar Ridge grew during a period of extreme hothouse conditions, where the global temperature is estimated between 23 and $28^{\circ} \mathrm{C}$, with an average temperature at the pole thought to have been above $0{ }^{\circ} \mathrm{C}$, versus $-50{ }^{\circ} \mathrm{C}$ today (Scotese 2015). Thus despite the high paleolatitude at which they grew $\left(75-85^{\circ} \mathrm{S}\right)$, these trees likely experienced some frost but no extremely cold temperatures during the growing season. The presence in the Central Transantarctic Mountains of forests with large-leaved trees and significant productivity (e.g., Taylor et al. 1992; Cúneo et al. 1993; Miller et al. 2016) supports this idea of a cold but temperate climate. 
No frost rings were observed in the wood of glossopterid trunks from Skaar Ridge (Taylor \& Ryberg 2007), but it is possible that this is in part due to the insulation provided by their bark. A thick insulating bark would have also protected the cambium from overheating during the permanent exposure to sunlight that the tree received during the summer months, and from sunscald in spring and fall. Sunscald damage occurs when part of the trunk is exposed to intense sunlight on cold days and suffers from repeated freeze/thaw episodes (Harvey 1923). Sunscald does not kill the trees but can provoke serious damage to the cambium and increases the susceptibility to pathogen attacks. At the high latitude where the Skaar Ridge glossopterids were growing, the risk of sunscald might have been high in spring and fall, particularly when the deciduous trees were leafless and the canopy did not shade the trunks.

A thick bark is also known to protect the cambium from fire damage. There is good evidence that wildfires occurred commonly throughout Gondwana in the Permian, including in high-latitude plant communities (Jasper et al. 2013). The occurrence of charcoal layers containing abundant remains of Vertebraria roots, Australoxylon wood, and Glossopteris leaves in Middle Permian deposits from the Prince Charles Mountains (Slater et al. 2015) support the idea that high-latitude glossopterid forests were subject to frequent wildfires. Although no analyses have been conducted yet, some layers of permineralized peat collected at Skaar Ridge contain dispersed plant fragments that are much darker than the surrounding material and might correspond to charcoal / fusain (R. Serbet 2015, pers. com.).

In addition to protecting the cambium and conducting secondary phloem against frost or heat damage, a thick bark would have also protected epicormic buds such as the ones documented in some of the Skaar Ridge trees (Decombeix et al.2010a). As in extant trees it would also have offered protection against insects and fungi that are known to have occurred in these high-latitude forests (e.g., Kellogg \& Taylor 2004; Slater et al. 2012; Harper et al. 2015, 2016).

When added to other characteristics, such as the ability to regenerate their crown via epicormic sprouts (Decombeix et al. 2010a), a diverse leaf habit (Gulbranson et al . 2014), or an hydraulic system adapted to limit risks of embolism (Wilson et al. 2014), the possession of a thick insulating bark would have surely provided advantages to the glossopterids during their conquest of high-latitude environments during the Permian. The same anatomical characters that suggest a resistance to frost also provide resistance to drought and fire and may have contributed to the success of the group in a variety of habitats and paleolatitudes.

\section{ACKNOWLEDGEMENTS}

The authors thank R. Serbet (Lawrence) for his help with the preparation of the specimens and C. Harper (Munich) for providing the map in Figure 1A. We also thank Pieter Baas and an anonymous reviewer for their helpful comments on an earlier version of the manuscript. AMAP (Botany and Computational Plant Architecture) is a joint research unit which associates CIRAD (UMR51), CNRS (UMR5120), INRA (UMR931), IRD (R123), and the University of Montpellier (UM); http://amap.cirad.fr/. 


\section{REFERENCES}

Artabe AE, Brea M \& Zamuner AB. 1999. Rhexoxylon brunoi Artabe, Brea et Zamuner, sp.nov., a new Triassic corystosperm from the Paramillo de Uspallata, Mendoza, Argentina. Rev. Palaeobot. Palynol. 105: 63-74.

Ash SR \& Savidge RA. 2004. The bark of the Late Triassic Araucarioxylon arizonicum tree from Petrified Forest National Park, Arizona. IAWA J. 25: 349-368.

Bamford M. 1999. Permo-Triassic fossil woods from the South African Karoo Basin. Palaeontologia Africana 35: 25-40.

Bomfleur B, Decombeix A-L, Escapa IH, Schwendemann AB \& Axsmith B. 2013. Wholeplant concept and environment reconstruction of a Telemachus conifer (Voltziales) from the Triassic of Antarctica. Int. J. Plant Sci. 174: 425-444.

Cantrill DJ \& Poole I. 2013. The vegetation of Antarctica through geological time. Cambridge University Press, Cambridge, UK.

Chan L-L. 1985. The anatomy of the bark of Libocedrus in New Zealand. IAWA Bull. n.s. 6: 23-34.

Chang Y-P. 1954. Bark structure of North American conifers. U.S.D.A. Tech. Bull. No. 1095.

Chattaway MM. 1953. The anatomy of bark. I. The genus Eucalyptus. Austr. J. Bot. 3: 39-47.

Cúneo NR, Isbell J, Taylor EL \& Taylor TN. 1993. The Glossopteris flora from Antarctica: Taphonomy and paleoecology. In: Archangelsky S (ed.),12 Congrès International de Géologie du Carbonifère-Permian, Buenos Aires, Compte Rendu, Vol. 2: 13-40. Buenos Aires, Argentina.

Decombeix A-L. 2013. Bark anatomy of an Early Carboniferous tree from Australia. IAWA J. 34: 183-196.

Decombeix A-L \& Meyer-Berthaud B. 2013. A Callixylon (Archaeopteridales, Progymnosperms) trunk with preserved secondary phloem from the Late Devonian of Morocco. Amer. J. Bot. 100: 2219-2230.

Decombeix A-L, Taylor EL \& Taylor TN. 2009. Secondary growth in Vertebraria roots from the Late Permian of Antarctica: a change in developmental timing. Int. J. Plant Sci. 170: $644-656$.

Decombeix A-L, Taylor EL \& Taylor TN. 2010a. Epicormic shoots in a Permian gymnosperm from Antarctica. Int. J. Plant Sci. 171: 772-782.

Decombeix A-L, Taylor EL \& Taylor TN. 2010b. Anatomy and affinities of permineralized gymnospermous trunks with preserved bark from the Middle Triassic of Antarctica. Rev. Palaeobot. Palynol. 163: 26-34.

Decombeix A-L, Taylor EL \& Taylor TN. 2012. Gymnosperm trees from the Permian of Antarctica: an anatomically preserved trunk of Kaokoxylon sp. C.R. Palevol. 11: 21-29.

Degani-Schmidt I \& Guerra-Sommer M. 2016. Charcoalified Agathoxylon-type wood with preserved secondary phloem from the lower Permian of the Brazilian Parana basin. Rev. Palaeobot. Palynol. 226: 20-29.

De Magistris AA \& Castro MA. 2001. Bark anatomy of southern South American Cupressaceae. IAWA J. 22: 367-383.

Den Outer RW. 1967. Histological investigations of the secondary phloem in gymnosperms. 1. Introduction. Meded. Landbouwhoges. Wageningen 67: 1-119.

Esau K. 1965. Plant anatomy. Ed. 2. John Wiley and Sons, New York.

Farabee MJ, Taylor EL \& Taylor TN. 1991. Late Permian palynomorphs from the Buckley Formation, central Transantarctic Mountains, Antarctica. Rev. Palaeobot. Palynol. 69:353-368.

Galtier J, Brown RE, Scott AC, Rex GM \& Rowe NP. 1993. A Late Dinantian flora from Weaklaw, East Lothian, Scotland. Palaeontology Special Papers 49: 57-74. 
Galtier J \& Phillips TL. 1999. The acetate peel technique. In: Jones TP \& Rowe NP (eds.), Fossil plants and spores: modern techniques: 67-70. The Geological Society, London.

Galtier J \& Scott AC. 1991. Stanwoodia, a new genus of probable early gymnosperms from the Dinantian of East Kirkton, Scotland. Trans. Roy. Soc. Edinburgh: Earth Sci. 82: 113-123.

Graça J \& Pereira H. 2004. The periderm development in Quercus suber. IAWA J. 25: 325335.

Grunow AM. 1999. Gondwana events and palaeogeography: a palaeomagnetic review. J.African Earth Sci. 28: 53-69.

Guerra-Sommer M, Cazzulo-Klepzig M, Jasper A, Kalkreuth W, Menegat R \& Barboza EG. 2008. Palaeoecological patterns at the coal-roof shale transition in an outcrop of the Permian Brazilian Gondwana. Rev. Brasileira de Paleontologia 11: 11-26.

Gulbranson EL, Ryberg PE, Decombeix A-L, Taylor EL, Taylor TN \& Isbell J. 2014. Leaf habit of Late Permian Glossopteris trees from high-paleolatitude forests. J. Geol. Soc. 171: 493-507.

Harper CJ, Taylor TN, Krings M \& Taylor EL. 2015. Fungi associated with Glossopteris (Glossopteridales) leaves from the Permian of Antarctica: A preliminary report. Zitteliana A 55: 107-114.

Harper CJ, Taylor TN, Krings M \& Taylor EL. 2016. Structurally preserved fungi from Antarctica: Diversity and interactions in late Paleozoic and Mesozoic polar forest ecosystems. Antarctic Science 28: 153-173.

Harvey RB. 1923. Cambial temperatures of trees in winter and their relation to sun scald. Ecology 4: 261-265.

Hass H \& Rowe NP. 1999. Thin sections and wafering. In: Jones TP \& Rowe NP (eds.), Fossil plants and spores: modern techniques: 76-81. The Geological Society, London.

Isbell JL \& Cúneo NR. 1996. Depositional framework of Permian coal-bearing strata, southern Victoria Land, Antarctica. Palaeogeogr. Palaeoclimatol. Palaeoecol. 125: 217-238.

Jasper A, Guerra-Sommer M, Abu Hamad AMB, Bamford M, Bernardes-de-Oliveira MEC, Tewari R \& Uhl D. 2013. The burning of Gondwana: Permian fires on the southern continent a palaeobotanical approach. Gondwana Research 24: 148-160.

Kenrick P \& Crane PR. 1997. The origin and early diversification of land plants: A cladistic study. Smithsonian Institution Press, Washington, DC. 441 pp.

Maheshwari HK. 1972. Permian wood from Antarctica and revision of some lower Gondwana wood taxa. Palaeontographica B 138: 1-43.

Marguerier J. 1973. Paléoxylologie du Gondwana Africain: Étude et affinités du genre Australoxylon. Palaeontologia Africana 16: 37-58.

McManus HA, Taylor EL, Taylor TN \& Collinson JW. 2002. A petrified Glossopteris flora from Collinson Ridge, central Transantarctic Mountains: Late Permian or Early Triassic? Rev. Palaeobot. Palynol. 120: 233-246.

McLoughlin S.2011. Glossopteris - insights into the architecture and relationships of an iconic Permian Gondwanan plant. J. Bot. Soc. Bengal 65: 1-14.

Meyer-Berthaud B \& TN Taylor. 1991. A probable conifer with podocarpacean affinities from the Triassic of Antarctica. Rev. Palaeobot. Palynol. 67: 179-198.

Miller MF, Knepprath NE, Cantrill DJ, Francis JE \& Isbell JL. 2016. Highly productive polar forests from the Permian of Antarctica. Palaeogeogr. Palaeoclimatol. Palaeoecol. 441: 292-304.

Mussa D. 1978. On the anatomy of wood showing affinities with the genus Vertebraria Royle, from the Irati Formation, State of São Paulo, Brazil. Bol. Inst. Geociências, Universidade de São Paulo (IG-USP) 9: 153-201. 
Neish PG, Drinnan AN \& Cantrill DJ. 1993. Structure and ontogeny of Vertebraria from silicified Permian sediments in East Antarctica. Rev. Palaeobot. Palynol. 79: 221-244.

Pigg KB \& Nishida H. 2006. The significance of silicified plant remains to the understanding of Glossopteris-bearing plants: An historical review. J. Torrey Bot. Soc. 133: 46-61.

Pigg KB \& Taylor TN. 1993. Anatomically preserved Glossopteris stems with attached leaves from the central Transantarctic Mountains, Antarctica. Amer. J. Bot. 80: 500-516.

Plumstead EP. 1956 . Bisexual fructifications borne on Glossopteris leaves from South Africa. Palaeontographica B 100: 1-25.

Prasad MNV \& Chandra S. 1978. Australoxylon from the Kamthi beds of Lower Gondwana, India. Current Science 47: 597.

Quilhó T, Sousa V, Tavares F \& Pereira H. 2013. Bark anatomy and cell size variation in Quercus faginea. Turk. J. Bot. 37: 561-570.

Ramanujam CGK \& Stewart WN. 1969. Taxodiaceous bark from the Upper Cretaceous of Alberta. Amer. J. Bot. 56: 101-107.

Retallack GT \& Dilcher DL. 1981. Arguments for a glossopterid ancestry of angiosperms. Paleobiology 7: 54-67.

Roth I. 1981. Structural patterns of tropical barks. Borntraeger, Berlin.

Scotese CR. 2002. PALEOMAP. Website: http://www.scotese.com/

Scotese CR. 2015. Some thoughts on global climate change: The transition for Icehouse to Hothouse conditions. https://www.researchgate.net/publication/275277369_Some_Thoughts_ on_Global_Climate_Change_The_Transition_for_Icehouse_to_Hothouse_Conditions

Scott DH. 1902. On the primary structure of certain Palaeozoic stems with the Dadoxylon type of wood. Trans. Roy. Soc. Edinburgh 40: 331-365.

Scott DH. 1924. Fossil plants of the Calamopitys type, from the Carboniferous rocks of Scotland. Trans. Roy. Soc. Edinburgh 53: 569-596.

Sen A, Quilhó T \& Pereira H. 2011. The cellular structure of cork from Quercus cerris var. cerris bark in a materials' perspective. Industrial Crops and Products 34: 929-936.

Slater BJ, McLoughlin S \& Hilton J. 2012. Animal-plant interactions in a Middle Permian permineralised peat of the Bainmedart Coal Measures, Prince Charles Mountains, Antarctica. Palaeogeogr. Palaeoclimatol. Palaeoecol. 363-364: 109-126.

Slater BJ, McLoughlin S \& Hilton J. 2015. A high-latitude Gondwanan lagerstätte: The Permian permineralised peat biota of the Prince Charles Mountains, Antarctica. Gondwana Research 27: $1446-1473$.

Stebbins GL. 1974. Flowering plants: Evolution above the species level. Belknap Press of Harvard University Press, Cambridge, Mass., USA.

Taylor EL. 1988. Secondary phloem anatomy in cordaitean axes. Amer. J. Bot. 75: 16551666.

Taylor EL \& Ryberg PE. 2007. Tree growth at polar latitudes based on fossil tree ring analysis. Palaeogeogr. Palaeoclimatol. Palaeoecol. 255: 246-264.

Taylor EL \& Taylor TN. 1990. Structurally preserved Permian and Triassic floras from Antarctica. In: Taylor TN \& Taylor EL (eds.), Antarctic paleobiology - its role in the reconstruction of Gondwana: 149-163. Springer-Verlag, New York, NY.

Taylor EL \& Taylor TN. 1992. Reproductive biology of the Permian Glossopteridales and their suggested relationship to flowering plants. Proc. Nat. Acad. Sci. USA 89: 11495-11497.

Taylor EL, Taylor TN \& Collinson JW. 1989. Depositional setting and paleobotany of Permian and Triassic permineralized peat from the central Transantarctic Mountains, Antarctica. Int. J. Coal Geo. 12: 657-679.

Taylor EL,Taylor TN \& Cúneo NR. 1992. The present is not the key to the past: A polar forest from the Permian of Antarctica. Science 257: 1675-1677. 
Taylor TN, Taylor EL \& Krings M. 2009. Paleobotany: The biology and evolution of fossil plants, Ed. 2. Academic Press, Burlington, MA, USA.

Weaver L, McLoughlin S \& Drinnan AN. 1997. Fossil woods from the Upper Permian Bainmedart Coal Measures, northern Prince Charles Mountains, East Antarctica. J. Austr. Geol. Geophys. 16: 655-676.

Wegener A. 1915. Die Entstehung der Kontinente und Ozeane. Vieweg \& Sohn, Braunschweig. Wilson JP, Miraglia GM \& Fischer WW. 2014. Physiology of Glossopteris, a circumpolar Permian seed plant, and implications for the terrestrial record of the Permian-Triassic mass extinction. Geological Society of America Annual Meeting, Vancouver, British Columbia, Canada (19-22 October 2014), Paper No.109-4. (https://gsa.confex.com/gsa/2014AM/ webprogram/Paper242441.html).

Accepted: 19 April 2016 